\title{
SOME FACTORS THAT AFFECT TRANSFER PRICING DECISION
}

\author{
Resa Pide Pratama Septiyani*1, Wita Ramadhanti², Yudha Aryo Sudibyo ${ }^{3}$ \\ 1,2,3Program Studi Akuntansi Fakultas Ekonomi dan Bisnis Universitas Jenderal Soedirman \\ Jl. HR. Boenyamin No. 708, Purwokerto 531222, Jawa Tengah, Indonesia \\ *Email Correspondence: resapide@yahoo.com
}

\begin{abstract}
The objectives of this research is to analyze the effect of tax minimization, firm size, foreign ownership bonus mechanism, and exchange rate on transfer pricing decision in multinational company engaged in manufacturing that listed on Indonesia Stock Exchange from the year of 2015 to 2016. Sampling method in this study is using purposive sampling using 8 criterias that have been determined. The result of binary regression analysis shows that only tax minimization that has positive effect on transfer pricing decision. While the others variable which are, firm size, foreign ownership, bonus mechanism, and exchange rate do not has an effect on transfer pricing decision.
\end{abstract}

Keywords: transfer pricing, tax minimization, firm size, foreign ownership, bonus mechanism, exchange rate

\begin{abstract}
Abstrak
Penelitian ini bertujuan untuk menganalisis pengaruh minimalisasi pajak, ukuran perusahaan, kepemilikan asing, mekanisme bonus, dan exchange rate terhadap keputusan transfer pricing perusahaan multinasional yang bergerak dalam bidang manufaktur yang terdaftar di Bursa Efek Indonesia dari tahun 2015 sampai 2016. Pengambilan sampel menggunakan purposive sampling dengan 8 kriteria yang telah ditentukan. Hasil penelitian dari tes regresi binari menunjukan bahwa hanya minimalisasi pajak yang mempunyai pengaruh positif terhadap keputusan transfer pricing. Sedangkan variabel lainnya yaitu, ukuran perusahaan, kepemilikan asing, mekanisme bonus, dan exchange rate tidak berpengaruh terhadap keputusan transfer pricing.
\end{abstract}

Keywords: transfer pricing, minimalisasi pajak, ukuran perusahaan, kepemilikan asing, mekanisme bonus, exchange rate

\section{INTRODUCTION}

ASEAN Economic Community (AEC) has been declared on December 31st, 2015. It opens a great opportunity for the creation of free ASEAN where access to transactions will be very easy. It almost has no boundaries for the countries in ASEAN. The traders, laborers, micro small and medium enterprises (SMEs) and companies will easily enter Indonesia and other countries in the ASEAN region. This is also certainly a great opportunity for multinational companies to expand, open new subsidiaries, even a transfer pricing.

In fact, transfer pricing has become one of the most visible and controversial topics in the global tax avoidance debate. It is supported by Ernst and Young's 2016 survey that the number of firms indicating tax risk management as their top transfer pricing priority has surged to 75\%, up from 66\% in their 2013 survey; in 2007 and 2010, that proportion was just 50\%.

Indonesia itself already has a high tax rate which is $25 \%$. Since then, it will motivate multinational companies to transfer the taxable income to a country with lower tax rates in order to reduce the total 
tax burden of the multinational corporation. Based on Directorate General of Taxation Indonesia, in 2012, from 1.161 Foreign Investment Tax Payers who transacted with affiliates abroad, a number of 436 taxpayers reported the Annual Tax Return has a loss with total affiliation amounting to Rp 76.22 trillion. This number increased rapidly in 2013, from 1,284 Taxpayers Foreign Investment Taxes who transacted with affiliates abroad, a number of 515 taxpayers reported the Annual Tax Return has a loss with total affiliated transactions amounting to Rp 269.33 trillion.

With the issuance of Base Erosian and Profit Shifting (BEPS) Action by the Organization for Economic Cooperation and Development (OECD), G-20 countries agreed to close loophole tranfer pricing by creating a more transparent international taxation world. Especially for Indonesia, the government has issued Government Regulation (PP) Number 74 of 2011 on Procedures for the Implementation of the Right and Fulfillment of Taxation Obligation, which is further stipulated in Regulation of the Minister of Finance (PMK) Number 213/PMK.03/2016 on Document Type and or Information Additional Compulsory Kept by Taxpayers Transacting with Related Parties and Management Procedures. This rule has been signed by Finance Minister Sri Mulyani Indrawati on December 30, 2016.

Research on the effect of a tax on transfer pricing itself has been done. Jacob (1996) found that transfers between large corporations can lead to lower global tax payments in general. So that the multinational corporation get benefit from the shift of revenues of countries with high taxes to countries with low taxes. Swenson (2001) finds that import tariffs and taxes have an effect on incentives for transfer pricing transactions. This is also in line with what Bernard et al., (2006) found that the price of related party transactions relates to the tax rate and tariff on imports of the destination country. In addition, Yuniasih et al., (2012), Hartanti (2014), and Refgia (2017) also found that the tax positively affects the company's decision to transfer pricing. One reason is to reduce the burden of taxes because in business practices generally, entrepreneurs identified tax payments as an expense so that it will always try to minimize the tax burden.

In addition to tax motivation, the decision to transfer pricing is also influenced by firm size. According to Rego (2003) states that larger firms typically engage in more business activities and financial transactions than smaller firms. Large companies have more complex operational activities than small firms, making it more likely to make earnings management. Moreover, Bernard et al., (2006) observed that larger firms engage in greater manipulation of transfer prices. Research conducted by Richardson, et al., (2013) proves that firm size has a positive effect on the company's decision to transfer pricing. But according to Kiswanto and Purwaningsih (2014) and Refgia (2017) found that firm size has a negative effect on transfer pricing decision.

Another thing that also affects the company's decision to transfer pricing is foreign ownership. Kiswanto and Purwaningsih (2014) and Refgia (2017) found that foreign ownership positively affects the company's decision to transfer pricing. Most Asian companies have a concentrated ownership 
Some Factors That Affect Transfer Pricing....

structure (Dynaty et al., 2012). The concentrated ownership structure tends to create a conflict of interest between the controlling shareholder and the non-controlling shareholder. Controlling shareholder under PSAK No. 15 is an entity that owns 20\% or more shares directly or indirectly so that the entity is considered to have a significant influence in controlling the company. The controlling shareholder may be owned by an individual, a government, or a foreign party. As share ownership of foreign controlling shareholders grows larger, the foreign controlling shareholder has greater control over the decisions within the company that benefit him so that controlling shareholder may misuse the right of control for his own welfare (Dionysia, 2013). One of them by transfer pricing. The foreign controlling shareholder sells the product from the company he or she controls to his private company for a price below the market. Based on the explanation it can be possible that foreign ownership may affect the least amount of transfer pricing that occurs.

Bonus mechanisms can also influence a company's decision to transfer pricing. According to Healey (1985) states that managers who have information on the company's net profit will act opportunistically to make earnings management by maximizing the profit of the current period. According to Lo et al. (2010) found that there is a tendency for management to take advantage of transfer pricing transactions to maximize the bonuses they receive if the bonuses are based on earnings. As Hartati et al. (2014), when the awarding of bonuses is based on the amount of profit, it is logical if the directors try to take action to manage and manipulate the profit in order to maximize the bonuses and remuneration they receive. But based on Refgia (2017) found that bonus mechanism does not influence transfer pricing decision, because, in her research sample, the profit data is more likely stable from the previous year to the recent year. It means that the companies sample are less interested in manipulating earnings and transfer pricing to maximize the bonus.

In addition to these factors, exchange rates can also influence the company's decision to transfer pricing. Cravens and Shearon Jr (1996) stated that in order to control the risks from profit or loss of transactions, the company can use transfer pricing as a protective fence to deal with changes in exchange rates. Transfer pricing can be used to reduce the exposure of multinational corporations' transactions on the risk of exchange rate changes by moving funds into strong currencies. According to Chan, Landry, and Jalbert (2004) states that multinational companies may try to curb foreign exchange rate risk by moving funds into strong currencies through transfer pricing to maximize overall corporate profits. Bernard et al., (2006) also found that there is an effect of exchange rate on transfer pricing decisions inside and outside the firm; an appreciation of the dollar reduces the difference between the prices. However, different from Marfuah and Azizah (2014) stated that the size of the exchange rate does not affect the company's consideration whether the company will choose to make transfer pricing decisions within the company. This is probably due to the company's financial statements, there are many losses on foreign exchange gains or losses so that the exchange rate does not become the main focus in management's tendency to utilize transfer pricing transactions. 
Based on the explanation in the research background, yet there is still a research gap between one previous research and the other then researcher is interested to conduct research entitled "The Effect of Tax Minimization, Firm Size, Foreign Ownership, Mechanism Bonus, and Exchange Rate to Transfer Pricing Decision (Empirical Study on Multinational Company Engaged in Manufacturing that Listed on Indonesia Stock Exchange in the Period of 2015 to 2016)”.

\section{LITERATURE REVIEW AND HYPOTHESIS DEVELOPMENT}

\subsection{Agency Theory}

Agency theory that introduced by Jensen and Meckling (1976) describes the relationship between agents and principals. The agency theory arises when there are two parties that are interconnected and mutually bound, where one party (the principal) employs another party (agent) to execute a number of services and authorizes the agent to make the best decision for the principal.

The agency relationship can cause an imbalance when there is information asymmetry. Information asymmetry is a situation where the agent has more information than the principal because the principal is not directly involved in the management of the company so that it does not have access to adequate information. Therefore, as a manager, the agent has an obligation to give a signal about the condition of the company to the owner (Ujiyantho and Pramuka 2007). If it is assumed that the individual acts for the purpose of maximizing self-interest, then the agent will tend to hide some information that the principal does not know. According to Ujiyantho and Pramuka (2007) information asymmetry that occurs between the agent with the principal provides an opportunity for agents to act opportunistically, namely acting in order to gain personal gain.

From the description above can be seen that there is a tendency where the agent can do transfer pricing especially with parties that have a special relationship. Based on PSAK No. 7 of 2010, related parties are those who have control over other parties or parties that may influence the decision-making. According to Jensen and Meckling (1976), transactions between related parties are seen as opportunistic transactions and may lead to the friction of interest between the transacting parties which is consistent with the agency theory.

Transactions between related parties or so-called transfer pricing are used for the purpose of maximizing corporate profits. If the agent utilizes information asymmetry to obfuscate principals and maximize self-interest to get bonus, transfer their asset, even to minimize the tax and maximize profit through transfer pricing, it is possible that agents do transfer pricing through manipulation transactions at unrealized prices. This study will examine influence of minimize tax payments, firm size, foreign ownership, bonus mechanism, and exchange rate on transfer pricing decisions.

\subsection{Tax and Transfer Pricing}


Tax minimization tends to create a conflict of interest between the government as a principal party with the multinational companies as the agent. Multinational companies, as a taxpayer, has an obligation to pay the corporate tax to the government. If the company does not pay the tax, they will get a sanction. The government itself believes that the tax is a large income for Indonesia. So the multinational companies must pay taxes in accordance with the amount that has been determined and set the provisions of taxation in the law, since it is their obligation as a taxpayer. But multinational companies assume that taxes are an expense to the company. So companies are trying to reduce taxes through tax planning by utilizing the existing holes in the law. One way is to do transfer pricing. This transfer pricing abuse will make government loss their income from the tax. But for the multinational companies, they will get their self interests which is a high profit by doing that kind of moral hazard to the government as their principal.

Jacob (1996) found that transfers between large corporations can lead to lower global tax payments in general. The study found that multinational corporations profited because of the shift of income from high-tax countries to low-tax countries. Then, Swenson (2001) found that tariffs and taxes had an effect on incentives for transfer pricing transactions. Bernard et al., (2006) also found that the price of related party transactions and arm's-length is related to the tax rate and tariff on imports of the destination country. In addition, Yuniasih et al., (2012), Hartanti (2014), and Refgia (2017) also found that the tax positively affects the company's decision to transfer pricing. One reason is to reduce the burden of taxes because in business practices generally, entrepreneurs identified tax payments as an expense so that they always try to minimize the tax burden.

Based on the above explanation, it can be concluded that if the company is in a country with high tax rates, this means the higher the level of activity of the company's pricing transfer will occur. This happens because the company will try to reduce the burden of one of the tax burden in order to reduce the cost of the company. So it can be formulated that the hypothesis in this study is as follows:

\section{$H_{1}$ : Tax minimization has a positive influence on transfer pricing decision}

\subsection{Firm Size and Transfer Pricing}

Large companies can be said also as a company that has a more complex management system and have a higher profit as well. So it can be said that the greater a company then the volume of transfer pricing more and more. Google, Starbucks, and Amazon are great examples of companies that are proven to transfer pricing due to partnerships and trusts.

According to Rego (2003) states that larger firms typically engage in more business activities and financial transactions than smaller firms. Moreover, Bernard et al., (2006) observed that larger firms engage in greater manipulation of transfer prices. Richardson et al., (2013) also found that larger firms (as opposed to smaller firms) tend to have substantial intercompany transactions that 
may have transfer pricing. But based on Kiswanto and Purwaningsih (2014) and Refgia (2017) found that firm size has a negative influence on transfer pricing decision.

Based on the above explanation, it can be concluded that the larger a company the greater the motivation to transfer pricing. This is because of the partnerships and trusts in the big companies themselves. So it can be formulated that the hypothesis in this study is as follows:

\section{$\mathrm{H}_{2}$ : Firm size has a positive influence on transfer pricing decision}

\subsection{Foreign Ownership and Transfer Pricing}

Foreign ownership tends to create a conflict of interest between the controlling shareholders as a principal party with the minority shareholders as the agent. A foreign party that has a share more than $20 \%$ can be called as a controlling shareholders because that foreign party has a significant influence and a majority shares in a company. This controlling shareholders can easily transfer the assets or even a profit to the outside of company using transfer pricing for their own selft interest, but the cost is paid by the minority one. The minority will suffer any kind of losses because of this moral hazard that has been done by the foreign ownership who has a controlling shareholder.

Research conducted by Kiswanto and Purwaningsih (2014) and Refgia (2017) shows that foreign ownership positively affects the company's decision to transfer pricing. Refgia (2017) found that the greater foreign ownership in a company, the greater their influence in deciding transfer pricing that this decision will give benefit to them. Dyanty et al., (2012) also stated that the higher the controlling rights of the controlling shareholder, including the foreign controlling shareholder, allowing the controlling shareholder to instruct the management to engage in related party transactions. It is also supported by Dionysia (2013) that stated as share ownership of foreign controlling shareholders grows larger, the foreign controlling shareholder has greater control over the decisions within the company that benefit him so that controlling shareholder may misuse the right of control for his own welfare. One of them by transfer pricing. The foreign controlling shareholder sells the product from the company he or she controls to his private company for a price below the market. Based on the explanation it can be possible that foreign ownership may affect the least amount of transfer pricing that occurs.

Based on the above explanation, it can be said that when the owner of shares owned by the holders of the foreign controlling is greater, the greater the opportunity to transfer pricing. This is because the foreign controlling shareholder has the right of control to determine the transfer pricing policy. So it can be formulated that the hypothesis in this study is as follows:

\section{$\mathrm{H}_{3}$ : Foreign ownership has a positive influence on transfer pricing decision}

\subsection{Bonus Mechanism and Transfer Pricing}


Bonus mechanism tends to create a conflict of interest between the board directors as a principal party with the key management as the agent. The key management has an obligation to do the mandate from board directors which is to run the company well and make a profit. But sometimes there is a condition that will make the company loss for a reason. The key management tries to make the profit looks good even when actually it is loss. So that, the key management will get bonus for the good performance which is make a lot of profit. One way is to do a transfer pricing transaction. But it will make suffer for the board directors because it is not the real profit.

According to Healey (1985) states that managers who have information on the company's net profit will act opportunistically to make earnings management by maximizing the profit of the current period. Research conducted by Lo et al., (2010) from America, found that there is a tendency of management to utilize transfer pricing transactions to maximize the bonuses they receive if the bonus is based on profit. This is also in line with research conducted by Hartati et al., (2014) shows the effect of bonus mechanisms on the decision of transfer pricing company. In order to get the bonus from the owner of the company, the directors will try as much as possible in order to increase overall profit of the company including by doing transfer pricing. But based on Refgia (2017) found that bonus mechanism does not influence transfer pricing decision, because, in her research sample, the profit data is more likely stable from the previous year to the recent year. It means that the companies sample are less interested in manipulating earnings and transfer pricing to maximize the bonus.

Based on the above explanation, it can be said that when the bonuses obtained by directors and managers are determined based on the overall profit of the company, the directors and managers will tend to take action to manage the company's earnings to look great by transfer pricing. Transfer pricing is done so that directors and managers can maximize the bonuses they receive. So it can be concluded that the greater the bonus that would be accepted by the directors and managers, the greater the motivation of directors and managers to do transfer pricing. So it can be formulated that the hypothesis in this study is as follows:

\section{$\mathrm{H}_{4}$ : Bonus mechanism has a positive influence on transfer pricing decision}

\subsection{Exchange Rate and Transfer Pricing}

Most multinational companies request exchange of one currency with another currency to make payments. However, the constantly fluctuating exchange rates result in the amount of cash needed to make payments also uncertain. The consequence is that the unit of currency of the country of origin required to pay for raw materials from abroad may vary even though the supplier does not change prices. This can cause a profit or loss for the company. Companies that want profit are more likely to use a stronger currency to express their cash. So as to reduce the risk of an exchange rate, multinational companies use transfer pricing to transfer funds to a strong currency. 
Cravens and Shearon Jr (1996) stated that in order to control the risks from profit or loss of transactions, the company can use transfer pricing as a protective fence to deal with changes in exchange rates. Transfer pricing can be used to reduce the exposure of multinational corporations' transactions on the risk of exchange rate changes by moving funds into strong currencies. According to Chan, Landry, and Jalbert (2004) states that multinational companies may try to curb foreign exchange rate risk by moving funds into strong currencies through transfer pricing to maximize overall corporate profits. Bernard et al., (2006) also found that there is an effect of exchange rate on transfer pricing decisions inside and outside the firm; an appreciation of the dollar reduces the difference between the prices.

Based on the above explanation, it can be said that the exchange rate affects cross-border transactions. Changes in the exchange rate of a currency will make the transactions that occur in favor of one of the parties involved in the transaction. So the more fluctuating the exchange rate, the higher the company's motivation to transfer pricing. This is because the company tries to reduce the risk through the practice of transfer pricing. So it can be formulated that the hypothesis in this study is as follows:

\section{$\mathrm{H}_{5}$ : Exchange rate has a positive influence on transfer pricing decision}

\section{RESEARCH METHODOLOGY}

\subsection{Type of Research}

The type of research used in this study is quantitative research that using financial statements of multinational companies engaged in manufacturing from Indonesia Stock Exchange in the period of $2015-2016$.

\subsection{Operational Definition and Measurement of Variable}

\subsubsection{Dependent Variable}

Transfer pricing is calculated by dichotomous approach when the company sells to a related party it will be assigned a value of 1 , whereas the company that does not sell to a related party will be assigned a value of 0 .

\subsubsection{Independent Variable}

\section{a. Tax Minimization}

Researchers used the Cash ETR proxy (cash tax payments) to measure the effective tax rate on the actual tax paid company. Cash ETR is the ratio of cash taxes paid to corporate earnings before income taxes (pretax income).

$$
\operatorname{CETR}_{i t}=\frac{\text { CashTaxesPaid }_{i t}}{\text { PretaxIncome }_{i t}}
$$

\section{b. Firm Size}


This study will use total assets to measure firm size because asset values are relatively more stable than sales (Sudarmaji and Sularto, 2009 in Kiswanto and Purwaningsih, 2014).

$$
\text { SIZE }=\text { Total Assets }
$$

\section{c. Foreign Ownership}

The measurement of the percentage in this study is measured using the proportion of ordinary shares held by foreign divided by the total shares outstanding. The amount of foreign ownership in question is the number of shares owned by a foreign party. While the total outstanding shares, calculated by adding up all shares issued by the company.

$$
\text { Foreign Owner Ship }=\frac{\text { Total Foreign Ownership }}{\text { Total Outstanding Shares }} \times 100 \%
$$

\section{d. Bonus Mechanism}

Bonus mechanism in this research is measured by a concept from Subekti and Sumargo (2015) in Ramadhanti and Indrayanto (2016) that is by using a proxy from total compensation value received by directors for one year.

$$
\text { BONUS = Total Bonus in One Year }
$$

\section{e. Exchange Rate}

The exchange rate is calculated from the profit or loss of sales by the following formula (Marfuah and Azizah, 2014):

$$
\text { Exchange Rate }=\frac{\text { Profit Loss on Foreign Exchange }}{\text { Profit Loss Before Tax }}
$$

\subsection{Data Analysis Technique}

\subsubsection{Descriptive Statistics Analysis}

According to Ghozali (2013), a descriptive statistic is statistic used to give a description or description of data seen from a mean value, standard deviation, variance, maximum, minimum, sum, range, and the other.

\subsubsection{Multicollinearity Test}


Multicollinearity test in this study is using correlation matrix between independent variables. If the value is less than 0.8 means that there is no correlation between independent variables in this research.

\subsubsection{Binary Regression Analysis}

Binary regression is a regression used to find the regression equation where the dependent variable (response variable) is categorical type of two options such as yes or no, or more than two options such as: disagree, agree, strongly agree. This study uses binary regression analysis because the dependent variable is measured by dichotomy variable ( 0 or 1$)$ and the independent variable is a mix between continuous (metric) and categorical (non-metric) variables. The regression model used to test the hypothesis is as follows:

$$
Y=\alpha+\beta_{1} X_{1}+\beta_{2} X_{2}+\beta_{3} X_{3}+\beta_{4} X_{4}+\beta_{5} X_{5}+e
$$

Notes:

$$
\begin{array}{ll}
\mathrm{Y} & =\text { Transfer Pricing } \\
\mathrm{X}_{1} & =\text { Tax Minimization } \\
\mathrm{X}_{2} & =\text { Company Size } \\
\mathrm{X}_{3} & =\text { Foreign Ownership } \\
\mathrm{X}_{4} & =\text { Bonus Mechanism } \\
\mathrm{X}_{5} & =\text { Exchange Rate } \\
\alpha & =\text { The value of } Y \text { if } \mathrm{X}=0 \\
\beta_{1}-\beta_{5} & =\text { Coefficient of Regression } \\
\mathrm{e} & =\text { Error or Residual }
\end{array}
$$

\section{RESULT AND DISCUSSION}

This research took a sample of companies that belong to multinational company engange in manufacturing that listed in Indonesia Stock Exchange in the period of 2015 - 2016. Based on observation in the official website of Indonesia Stock Exchange (www.idx.co.id), there are 144 companies belonging to the category of manufacturing sub-sector.

Sampling method in this research using purposive sampling with total 8 predetermined criteria. There are 23 companies that meet the criteria of the research sample. The number of companies is 23 with 2 years of time period observation so the amount of research sample is 46 companies. The rest of the companies is excluded from the research sample because they are not meet the criteria that have been determined. 
Table 1

Sample Selection with Purposive Sampling Method

\begin{tabular}{|l|l|l|}
\hline No & Criteria & Total \\
\hline 1 & $\begin{array}{l}\text { Multinational companies engaged in the manufacturing sector that listed on } \\
\text { Indonesia Stock Exchange in the period of 2015 - 2016 }\end{array}$ & 144 \\
\hline 2 & Companies did not completely publish financial statement during 2015-2016 & $(13)$ \\
\hline 3 & Companies suffered any losses during 2015 - 2016 & $(48)$ \\
\hline 4 & Companies' foreign ownership is less than 20\% & $(2)$ \\
\hline 5 & Companies did not have foreign ownership data & $(41)$ \\
\hline 6 & Companies did not have the key management's bonus data & $(7)$ \\
\hline 7 & Companies did not have profit/loss on exchange rate data & $(4)$ \\
\hline 8 & Companies did not use Rupiah as their currency & $(6)$ \\
\hline Number of companies that fulfilled the criteria & 23 \\
\hline \multicolumn{2}{|l|}{ Total research sample during 2015 - 2016 (23x2) } & 46 \\
\hline
\end{tabular}

\subsection{Descriptive Statistics Analysis}

The dependent variable in this research is transfer pricing has a minimum value of 0 and a maximum value of 1 with a standard deviation value of 0.34050 . The average value of the transfer pricing variable is 0.8696 . This means that $86.96 \%$ of the 46 samples are as many as 40 sample companies do a transaction of transfer pricing.

Variable tax minimization which is the independent variable in this research has a minimum value equal to -31.78 and a maximum value equal to -0.07 . The mean value of variable tax minimization is -1.0783 with a standard deviation of 4.65904 . This indicates that the average company pays taxes by cash of 1.0783 from the value of profit before tax.

Variable firm size which is the independent variable in this study has a minimum value of 12.00 and a maximum value of 29.00 . The mean value of the firm size variable is 22.2391 with the standard deviation of 5.65758. This shows that the total assets of the sample company are large and vary greatly.

Variable foreign ownership which is the independent variable in this study has a minimum value of -0.12 and a maximum value of 0.99 . The mean value of the foreign ownership variable is 0.5730 with the standard deviation of 0.25144 . This shows that the average sample company has a foreign ownership of $57.30 \%$. So it can be said that the foreign ownership in the sample company tends to concentrate on a few parties.

Variable bonus mechanism which is the independent variable in this research has a mean value of bonus mechanism variable is equal to 17.2826 with standard deviation value of 5.76064 . While a minimum value of 7.00 and a maximum value of 25.00. This suggests that the amount of bonuses given to key inter-company managers varies greatly depending on the number of directors and firm size.

The exchange rate variable which is the independent variable in this study has a mean value of the exchange rate variable is -0.6079 . This is because the range of exchange rate variation is quite 
high, indicated by the magnitude of the difference from a maximum value of 0.56 with a minimum value of -25.29 with a standard deviation of 3.73535 .

\subsection{Multicollinearity Test}

Matrix correlation shows there is no correlation coefficient between independent variables whose value is greater than 0.8 . This means there is no symptom of multicollinearity between independent variables in this study.

\subsection{Binary Regression Analysis}

The first step is to test the overall model fit test using -2 Log Likelihood. the value at -2 Log Likelihood (-2LogL) initial (Block Number $=0$ ) is 35.624. While at -2 Log Likelihood (-2LogL) end (Block Number $=1$ ) decreased value after the inclusion of the independent variable in this research, the value of $-2 \log L$ become equal to 26.701 . This decrease shows a good regression model or in other words the hypothesized fit model with the data, it means that the addition of independent variables such as tax minimization, firm size, foreign ownership, bonus mechanism, and the exchange rate will improve the research fit model.

The second step is to assess the eligibility of the regression model using Hosmer and Lemeshow's Goodness of Fit Test. It shows the significance value greater than 0.05 that is equal to 0.706. This means $\mathrm{H}_{\mathrm{o}}$ is accepted or in other words that there is no difference between the model and the data. So it can be concluded that the regression model is feasible for use in further analysis.

Then the third step is to find out how big the variability of the independent variables consisting of tax minimization variable, firm size, foreign ownership, bonus mechanism, and exchange rate, can explain the variability of the dependent variable that is transfer pricing using Nagelkerke R Square. It shows the value of Nagelkerke R Square is 0.327 . This means that $32.7 \%$ of pricing transfer variables can be explained by tax minimization, firm size, foreign ownership, bonus mechanism, and exchange rate variables. While the rest of $67.3 \%$ is explained by other factors outside the model that is being analyzed.

\section{a. The Effect of Tax Minimization on Transfer Pricing}

The value of significance for tax minimization variable is smaller than $\alpha=0.05$ which is equal to 0.038 with a positive coefficient of 2.641 . This means that the variable tax minimization significantly influences positively on the transfer pricing decisions in the multinational manufacturing sector in 2015 - 2016. So it can be concluded that the higher the tax burden of a company, the higher the transfer pricing activities within the company.

The tax itself is considered as a burden by the company, if the tax burden is greater then the profit earned by the company will be smaller. Whereas most companies try to achieve profits as big as possible. The average sample company in this study paid taxes by cash of $107.83 \%$ of the value of profit before tax, meaning that the tax burden of the company can be said to be higher than its profit. 
So for that reason, the company will try to minimize minimum tax payments to reduce the tax burden. One way is the company transfers some income to another country that has a low tax rate to minimize tax payments through transfer pricing.

This research result supports the agency theory and in accordance with research conducted by Yuniasih et al., (2012), Hartanti et al., (2014), and Refgia (2017) which states that the tax positively affects the company's decision to do transfer pricing. One reason is to reduce the burden of taxes because in business practices generally, entrepreneurs identified tax payments as an expense so that they always try to minimize the tax burden. Bernard et al., (2006) also found that the price of related party transactions and arm's-length is related to the tax rate and tariff on imports of the destination country. Then, Swenson (2001) found that tariffs and taxes had an effect on incentives for transfer pricing transactions.

\section{b. The Effect of Firm Size on Transfer Pricing}

The value of significance for firm size variables greater than $\alpha=0.05$ is equal to 0.998 with a negative coefficient of -0.002 . This means that firm size variables do not affect the transfer pricing decisions in the multinational manufacturing sector in 2015 - 2016. So it can be concluded that the larger firm size of a company, the less transferred activity pricing in the company.

In this study, the firm's own size is measured using total assets in one year. As the total assets in the company grow larger then the company is considered as a big company. Large companies alone have more partners than small companies. So large companies tend to do transfer pricing because of the partnership and trust. However, this study found that the larger firm size of a company, the less the transfer pricing activity in the company. This is because the sample company in this study is a company that is listed on Indonesia Stock Exchange, which means anyone can access the company's financial statements easily. When a company's financial statements can be easily accessed by the public at large, the company will be more cautious in reporting the company's financial condition because it feels that it is being watched by the public and the government. Moreover, big companies that already have a name, they will be more careful to keep their financial statements look good and avoid the practice of transfer pricing. Therefore, it can be concluded that the greater firm size of a company, the less transferred activity pricing within the company.

The results of this study are consistent with studies conducted by Refgia (2017) also Kiswanto and Purwaningsih (2014), but not in accordance with research conducted by Bernard et al., (2006) and Richardson et al., (2013) who found that larger firm engage in greater manipulation of transfer prices and tend to have substantial intercompany transactions that may have transfer pricing.

\section{c. The Effect of Foreign Ownership on Transfer Pricing}

The value of significance for foreign ownership variables greater than $\alpha=0.05$ is equal to 0.075 with a negative coefficient of -5.002 . This means that the variable of foreign ownership does 
not affect the transfer pricing decision in the multinational company in the manufacturing sector in 2015 - 2016. So it can be concluded that the greater the foreign ownership of a company, the less the transfer pricing activity in the company.

The foreign ownership in this study is calculated based on the number of shares of foreign parties divided by a total number of shares. If the result is more than $20 \%$ then indicates that the foreign party has a significant influence on the company including to determine the amount of transfer pricing made by the company for the interests of the foreign party itself. But the sample companies in this study are multinational companies that have control of branch companies without any special relationship in the form of family blood. Therefore, although the foreign party has a significant influence because it has a share of more than $20 \%$, it is not justified if in determining decisions in companies at the organizational scale including transfer pricing can be done easily by the foreign party. This is due to the need for agreement and approval from the company's board of directors.

This research result supports the agency theory but not in accordance with research by Kiswanto and Purwaningsih (2014) also Refgia (2017) shows that foreign ownership positively affects the company's decision to transfer pricing. Refgia (2017) found that the greater foreign ownership in a company, the greater their influence in deciding transfer pricing that this decision will give benefit to them. Dyanty et al., (2012) also stated that the higher the controlling rights of the controlling shareholder, including the foreign controlling shareholder, allowing the controlling shareholder to instruct the management to engage in related party transactions.

\section{d. The Effect of Bonus Mechanism on Transfer Pricing}

The value of significance for bonus mechanism variables greater than $\alpha=0.05$ that is equal to 0.883 . This means that the bonus mechanism variable does not affect the transfer pricing decisions in the multinational manufacturing sector in 2015 - 2016. But the positive coefficient of 0.091, it means there is a positive relationship between the bonus mechanism with transfer pricing, the increased value of bonus mechanism, the more the transaction transfer pricing.

Bonus mechanism in this study is proxied using total bonus received by key management for one year. The average bonuses given to key management in the sample company decreased from 2015 to 2016. This resulted in a decrease in key management motivation for earning management using transfer pricing. So the main focus of key management to make profit management will be reduced because of the lack of appreciation they get from year to year. Key management feels in vain when they transfer pricing to increase profits, it only benefits shareholders only because the bonuses they get instead of getting less. So the intensity of transfer pricing within the company will decrease due to the reduced bonuses that key management gets.

This research result supports the agency theory. Bonus mechanism tends to create a conflict of interest between the board directors as a principal party with the key management as the agent. 
The key management has an obligation to do the mandate from board directors which is to run the company well and make a profit. But sometimes there is a condition that will make the company loss for a reason. The key management tries to make the profit looks good even when actually it is loss. So that, the key management will get bonus for the good performance which is make a lot of profit. One way is to do a transfer pricing transaction. But it will make suffer for the board directors because it is not the real profit.

The results of this study are in accordance with Refgia (2017), that found, bonus mechanism does not influence transfer pricing decision, because, in her research sample, the profit data is more likely stable from the previous year to the recent year. It means that the companies sample are less interested in manipulating earnings and transfer pricing to maximize the bonus. But not in accordance with research conducted by Hartanti et al., (2014) and Lo et al., (2010) from America. Hartanti et al., (2014) which states that the bonus mechanism significantly positive effect on transfer pricing decisions. In order to get the bonus from the owner of the company, the directors will try as much as possible in order to increase overall profit of the company including by doing transfer pricing. Lo et al., (2010) from America, found that there is a tendency of management to utilize transfer pricing transactions to maximize the bonuses they receive if the bonus is based on profit.

\section{e. The Effect of Exchange Rate on Transfer Pricing}

The value for exchange rate variable is greater than $\alpha=0.05$ is equal to 0.117 with a negative coefficient value of -5.354 . This means that the variable exchange rate does not affect the transfer pricing decisions in the multinational manufacturing sector in 2015 - 2016. So it can be concluded that the greater the exchange rate of a company, the less transferred activity pricing in the company.

The exchange rate in this study is proxied using profit/loss on foreign exchange divided by profit before tax. The average sample companies in this study experienced loss on foreign exchange. So the exchange rate in this study did not affect the decision to transfer pricing. The existence of such losses makes the company think that changes in exchange rates do not provide benefits for the company one of them due to weakening domestic currency that causes the company to lose in transactions with foreign parties using the exchange rate. So it can be concluded that companies tend not to make transfer pricing just because of the exchange rate.

The results of this study in accordance with research conducted Marfuah and Azizah (2014) which states that the exchange rate does not affect the company in taking transfer pricing decisions. But not in accordance with research conducted by Chan, Landry, and Jalbert (2004) and Bernard et al., (2006). According to Chan, Landry, and Jalbert (2004) states that multinational companies may try to curb foreign exchange rate risk by moving funds into strong currencies through transfer pricing to maximize overall corporate profits. Bernard et al., (2006) also found that there is an effect 
of exchange rate on transfer pricing decisions inside and outside the firm; an appreciation of the dollar reduces the difference between the prices.

\section{CONCLUSION}

Based on the result of research, only tax minimization that has a positive effect on transfer pricing decisions. While firm size, foreign ownership, bonus mechanism, and exchange rate do not have effect on transfer pricing decision.

This research result consisten with the agency theory, provide an overview of the factors that influence the company taking the decision to transfer pricing, especially multinational companies in Indonesia, and also add reference to future research in accounting field. For the government, this research is expected to be able to provide an understanding about how tax minimization, firm size, foreign ownership, bonus mechanism, and exchange rate influence the company to take the decision to do a transfer pricing transaction. So it can be used as an evidence to find out more about transfer pricing abuse in a company.

Independent variables in this research are tax minimization, firm size, foreign ownership, bonus mechanism, and exchange rate that only has the value of Nagelkerke R Square is 0.327 . This means that $32.7 \%$ of pricing transfer variables can be explained by tax minimization, firm size, foreign ownership, bonus mechanism, and exchange rate variables. While the rest of $67.3 \%$ is explained by other factors outside the model that is being analyzed.

Further research is expected to add other factors that may affect the company's decision to transfer pricing, such as the debt to equity ratio (DER) and use more samples and timeseries of the company in order to be generated under existing conditions in Indonesia.

\section{REFERENCE}

Atmaja, L. (2011). Who Wants To Be Rational Investor. Kepustakaan Populer Gramedia. Jakarta.

Biro Analisis Anggaran dan Pelaksanaan APBN. (2014). Potensi Penerimaan Pajak Dengan Minimalisir Praktik Transfer Pricing. http://www.dpr.go.id/doksetjen/dokumen/apbn_potensi_penerimaan_pajak_dengan_minimalisir_prakt ek_transfer_pricing2010821142540.pdf, accessed on $18^{\text {th }}$ of Desember 2017.

Bernard, A. B., Jensen, J. B., and Schott, P. K. (2006). Transfer Pricing By US-Based Multinational Firms. National Bureau of Economic Research, Paper 12493.

Chan, C., Landry S. P. and Jalbert T. (2004). Effects of Exchange Rate on International Transfer pricing Decisions. International Business and Economics Research, Vol. 3, No. 3, 35-48.

Cravens, K. S and W. T. Shearon, Jr. (1996). An Outcome-Based Assessment Of International Transfer pricing Policy. The International Journal of Accounting, Vol. 31. No. 4, 419-443.

Darussalam and Sepriadi, D. (2008). Konsep dan Aplikasi Cross-Border Transfer Pricing Untuk Tujuan Perpajakan. Danny Darussalam Tax Center. Jakarta.

$\begin{array}{lllll}\text { Deloitte. } & \text { (2017). Corporate } & \text { Tax } & \text { Rates } & \end{array}$ https://www2.deloitte.com/content/dam/Deloitte/global/Documents/Tax/dttl-tax-corporate-taxrates.pdf, accessed on $4^{\text {th }}$ of January 2018.

Dionysia, K. (2013). Merger dan Akuisisi. Makalah. Program Pascasarjana Universitas Gunadarma. 
Direktorat Jenderal Pajak. (2015). DPJ Sukses Hentikan Tren Rugi Perusahaan Multinasional. http://www.pajak.go.id/content/article/djp-sukses-hentikan-tren-rugi-perusahaan-multinasional, accessed on $18^{\text {th }}$ of Desember 2017.

Dynaty, V., Utama S., Rossieta H., and Veronica S., (2012). Pengaruh Kepemilikan Pengendali Akhir Terhadap Transaksi Pihak Berelasi. Jurnal dan Prosiding SNA-Simponsium Nasional Akuntansi.

Ernst and Young. (2016). 2016 Transfer Pricing Survey Series In The Sportlight A New Era Of Transparency And Risk. http://www.ey.com/Publication/vwLUAssets/EY-2016-transfer-pricing-survey-series/\$FILE/EY-2016transfer-pricing-survey-series.pdf, accessed on 18 ${ }^{\text {th }}$ of Desember 2017.

Gayatrie, C. R. (2014). Skema Bonus dalam Keputusan Akuntansi Manajer. JABPI, Vol. 22, No. 2. Politeknik Negeri Semarang.

Ghozali, I. (2013). Analisis Multivariate Lanjutan Dengan Program SPSS. Badan Penerbit Universitas Diponegoro. Semarang.

Goeltom, M., and Doddy Z. (1998). Manajemen Nilai Tukar di Indonesia dan Permsalahannya. Journal Banking Indoensia.

Gravetter, F. J., and Lori-Ann B. F. (2015). Research Methods for Behavioral Sciences. Cengage Learning. Stamford.

Hanum, Hashemi Rodhian. (2013). Pengaruh Karakteristik Corporate Governance Terhdapat Effective Tax Rate (ETR). Skripsi. Universitas Diponegoro.

Hartati, W. D., and Nur A. (2014). Analisis Pengaruh Pajak Dan Mekanisme Bonus Terhadap Keputusan Transfer Pricing (Studi Empiris Pada Seluruh Perusahaan Yang Listing Di Bursa Efek Indonesia). Simposium Nasional Akuntansi 17 Mataram, Lombok Universitas Mataram 24-27 Sept 2014.

Healy, P. (1985). The effect of Bonus Schemes on Accountings Decision. Journal of Accounting and Economics, Vol. 7, 85-107.

Irpan. 2010. Analisis Pengaruh Skema Bonus Direksi, jenis Usaha, Profitabilitas Perusahaan, dan Ukuran Perusahaan Terhadap Earning Management: Studi Empiris Pada Perusahaan Manufaktur dan Keuangan yang Listing Di BEI Paada Tahun 2008-2010. Skripsi. Fakultas Ekonomika dan Bisnis. UIN Syarif Hidayatullah. Jakarta.

Jacob, J. (1996). Taxes and Transfer Pricing: Income Shifting and The Volume of Intrafirm Transfer. Journal of Accounting Research, Vol. 34, No. 2, 301-312.

Jensen, M., and W.H. Meckling. (1976). Theory of the Firm: Managerial Behavior, Agency Cost and Ownership Structure. Journal of Financial Economics, Vol. 3, No. 4, 305-360.

Kiswanto, N., and Purwaningsih, A. (2014). Pengaruh Pajak, Kepemilikan Asing, Dan Ukuran Perusahaan Terhadap Transfer pricing Pada Perusahaan Manufaktur Di BEI Tahun 2010-2013. E-Journal Universitas Atma Jaya. http://e-journal.uajy.ac.id/ accessed on 31 th of Desember 2017.

La Porta, R., F. Lopez-de-Silanes, A. Shleifer, and R.W. Vishny. (2000). Investor Production and Corporate Governance. Journal of Financial Economic, 3-27.

Liu, Q., and Z. Lu. (2007). Corporate Governance and Earnings Management in The ChineseListed Companies: A Tunneling Perspective. Journal of Corporate Finance, Vol. 13, 881-906.

Lo, W. Y. A., Raymond. M.K.W., and Micheal F. (2010). Tax, Financial Reporting, and Tunneling Incentives for Income Shifting: An Empirical Analysis of the Transfer Pricing Behavior of Chinese-Listed Companies. Journal of the American Taxation Association, Vol. 32, No. 2, 1-26.

Marfuah and Azizah, A.P.N. (2014). Pengaruh Pajak, Tunneling Incentive Dan Exchange Rate Pada Keputusan Transfer Pricing Perusahaan. JAAI, Volume 18 No. 2, 156-165.

Mutaminah. (2008). Tunneling atau Value Added dalam Strategi Merger dan Akuisisi di Indonesia. Manajemen \& Bisnis, Vol. 7, No. 1.

Natasari, E.Y. (2014). Pengaruh Business Risk, Non Debt Tax Shield, Devidend Payout Ratio dan Tangibility Asset Terhadap Penggunaan Hutang. Skripsi. Universitas Diponegoro.

Peraturan Direktur Jenderal Pajak Nomor PER-32/PJ/2011 tentang Penerapan Prinsip Kewajaran dan Kelaziman Usaha dalam Transaksi Antara Wajib Pajak dengan Pihak yang Mempunyai Hubungan Istimewa.

Peraturan Menteri Keuangan No. 213/PMK.03/2016 tentang Jenis Dokumen Dan/ Atau Informasi Tambahan yang Wajib Disimpan Oleh Wajib Pajak yang Melakukan Transaksi Dengan Para Pihak yang Mempunyai Hubungan Istimewa, dan Tata Cara Pengelolaannya.

Peraturan Pemerintah Republik Indonesia Nomor 74 Tahun 2011 Tentang Tata Cara Pelaksanaan Hak Dan Pemenuhan Kewajiban Perpajakan.

Pernyataan Standar Akuntansi Keuangan (PSAK) Nomor 7 tentang Pengungkapan Pihak-Pihak yang Mempunyai Hubungan Istimewa.

Pernyataan Standar Akuntansi Keuangan (PSAK) Nomor 15 tentang Investasi Pada Entitas Asosiasi dan Ventura Bersama.

Powsen, S. (1998). Corporate Governance, Emerging Issues and Lesson from East Asia. http://www.worlbank.org, accessed on $18^{\text {th }}$ of Desember 2017. 
Pujiningsih, A.I. (2011). Pengaruh Struktur Kepemilikan, Ukuran Perusahaan, Praktik Corporate Governence dan Kompensasi Bonus Terhadap Manajemen Laba. Skripsi. Universitas Diponegoro.

Purwanti, L. (2010). Kecakapan Managerial, Skema Bonus, Managemen Laba, dan Kinerja Perusahaan. Jurnal Aplikasi Manajemen, Vol. 8, No. 2.

Ramadhanti, W., and Indrayanto, A. (2016). Pengujian Power Theory pada Skema Remunerasi Pimpinan Puncak Perusahaan Publik di Indonesia. Jurnal Aplikasi Manajemen, Vol. 14, No. 4.

Refgia, T. (2017). Pengaruh Pajak, Mekanisme Bonus, Ukuran Perusahaan, Kepemilikan Asing, dan Tunneling Incentive Terhadap Transfer Pricing Perusahaan. JOM Fekon Vol. 4 No.1 (Februari) 2017.

Resmi, S. (2013). Perpajakan Teori dan Kasus. Salemba Empat. Jakarta.

Rego, S.O. (2003). Tax-Avoidance Activities Of U.S. Multinational Corporations. Contemporary Accounting Research, Vol. 20, No. 4, 805-33.

Richardson, G., Taylor, G., and Lanis, R. (2013). Determinants of Transfer Pricing Aggressiveness: Empirical Evidence from Australian Firms. Journal of Contemporary Accounting and Economics.

Setiawan, H. (2014). Transfer Pricing dan Risikonya Terhadap Penerimaan Negara. http://www.kemenkeu.go.id/sites/default/files/2014_kajian_pprf_transfer\%20pricing\%20dan\%20risi konya\%20terhadap\%20penerimaan\%20negara.pdf, accessed on $18^{\text {th }}$ of Desember 2017.

Sheifer, A, and R.W. Vishny. (1997). A Survey of Corporate Governance, Journal of Financial Economics, 737-783.

Subekti, I., and D.K. Sumargo. (2015). Family Management, Executive Compensation and Financial Performance of Indonesian Listed Companies. Procedia - Social and Behavioral Scriences, Vol.211, 578-584.

Sudarmaji, A.M., and Sularto, L. (2009). Pengaruh Ukuran Perusahaan, Profitabilitas, Leverage dan Tipe Kepemilikan Perusahaan Terhadap Luas Voluntary Disclosure Laporan Keuangan Tahunan. Skripsi. Universitas Gunadarma.

Sugiyono. (2012). Metode Penelitian Bisnis. Alfabeta. Bandung.

Sulistiono. (2010). Pengaruh Kepemilikan Manajerial, Struktur Modal dan Ukuran Perusahaan Terhadap Nilai Perusahaan Pada Perusahaan Manufaktur di BEI Tahun 2006-2008. Undergraduate Thesis. Universitas Negeri Semarang.

Suryatiningsih, N., and Siregar, S.V. (2008). Pengaruh Skema Bonus Direksi Terhadap Aktivitas Manajemen Laba: Studi Empiris Pada BUMN Periode Tahun 2003-2006. Jurnal Simposium Nasional Akuntansi, Vol. 11.

Swenson, D. L. (2001). Tax Reforms and Evidence of Transfer Pricing. National Tax Journal, Vol. LIV, No. 1, 7-25.

Ujiyantho, A., and Pramuka, B.A. (2007). Mekanisme Corporate Governance, Manajemen Laba dan Kinerja Keuangan (Studi Pada Perusahaan Go Publik Sektor Manufaktur). Jurnal dan Prosiding SNA-Simposium Nasional Akuntansi.

Undang-Undang Nomor 25 Tahun 2007 tentang Penanaman Modal.

Undang-Undang Nomor 20 Tahun 2008 tentang Usaha Mikro, Kecil dan Menengah.

Undang-Undang Nomor 16 Tahun 2009 tentang Ketentuan Umum dan Tata Cara Perpajakan.

Yuniasih, N.W., Rasmini, N.R., and Wirakusuma, M.G. (2012). Pengaruh Pajak dan Tunneling Incentive pada Keputusan Transfer Pricing Perusahaan Manufaktur yang Listing di Bursa Efek Indonesia. Jurnal Simposium Nasional Akuntansi, Unikal XV.

Zhuang, J., E. David, W. David, M.A.C. Virginita. (2000). Corporate Governace and Finance in East Asia- A Study of Indonesia, Republic of Korea, Malaysia, Philippines and Thailand. Asia Development Bank. Manila. 